\title{
Experimentation of The Use of Miniature Car For Learning Achievement on Mathematics on SDIT MTA Gemolong Regency of Sragen Year 2015/2016 Students
}

\author{
Herry Agus Susanto \\ Universitas Veteran Bangun Nusantara \\ Sukoharjo, Indonesia \\ herryanto62@yahoo.co.id
}

\author{
Djatmiko Hidajat \\ Universitas Veteran Bangun Nusantara \\ Sukoharjo, Indonesia \\ djatmikohidajat@gmail.com
}

\begin{abstract}
The purpose of this study is to determine whether there are differences in mathematics learning achievement between students who were taught by using a miniature car with students taught by conventional methods in fourth grade students of SDIT MTA Gemolong Sragen regency for academic year 2015/2016. This research is a quasi experimentation research conducted at SDIT MTA Gemolong Sragen Regency.
\end{abstract}

Keywords - learning motivation, mathematics learning achievement, miniature car.

\section{INTRODUCTION}

Human resources determine the progress of a nation, the progress of a nation can not be separated from quality education because from where the birth of human resources. Therefore improvement in education for the achievement of the quality of education should always be done, According [1] "... the skills and practices of the growing media around us have a central role in the lives of children and adolescents today presenting a more complex relationship than just ICT education and media" in line with that opinion [2] "the importance of incorporating the use of new media technologies pedagogically with a greater focus on media literacy education". Thus one that needs to be developed in education is the way or model used by teachers in teaching, so the need for an innovative and effective learning activities to achieve the goals to be achieved. The learning activities usually done by teachers today are the use of conventional methods.

In the conventional method students are required to listen to what is explained by the teacher in front of the class so that students are less active during the learning process takes place. In the learning of teachers convey and present the subject matter through various methods such as discussion, question and answer and assignment. The teacher explains by giving some examples and the students are asked to apply into the problem that matches the example that has been given previously. When students are asked about their understanding, students simply agree that they already understand. But when the teacher gives the problem with a different type, there are still many students who can not finish. After being asked, there are still many students who have not understood the example that has been given before through conventional methods.
Based on the results of interviews with one of the mathematics teachers of SDIT MTA of Gemolong, the problem faced today is how to improve the students' learning achievement in the lesson less than the predefined KKM. This is based on the results of a semester student reexamination that the average value is less than equal to 68 . And according to Reyhan one of the fourth grade students of SDIT MTA Gemolong said that mathematics is a very difficult lesson so the value obtained is less than the value of KKM. In addition, other factors are ways or methods used by teachers less fun or boring.

Learning is a mental or psychic activity that takes place in an active interaction with the environment that results in changes in knowledge of understanding, skills and attitudinal values. The changes are relative and traceable. According to [3] there are several definitions of learning, among others can be described as follows:

a. Cronbach gives a definition: Learning is shown by a change in behavior as a result of experience.

b. Harold Spears provides limits: Learning is to observe, to read, to imitate, to try something yourself, to listen, to follow direction.

c. Geoch, says: Learning is a change in performance as a result of practice.

Likewise, [4] states that "... that documentation which links knowledge processes explicitly to outcomes enables both teachers and learners to be more purposeful about the way learning goals are set and met. Such explicitness also allows for adjustment to meet the specific learning needs of learners in diverse classrooms ".

Of the four definitions above, it can be explained that learning is always a change in behavior or appearance, with a series of activities such as by reading, observing, listening, imitating and so forth. Changes are not only related to the addition of science, but also in the form of skills, skills, attitudes, understandings, self-esteem, interests, temperament, self-adjustment. Learning activities have several purposes, including:

a. Knowing a cleverness, skill, or concept that was previously unknown.

b. Can do something that previously could not be made, either behavior or skill.

c. Able to combine two knowledge (or more) into a new understanding of both skills, knowledge, concepts, and attitudes and behavior. 
d. Be able to understand and apply the knowledge gained.

According to Gagne [3] learning can also be interpreted as a change in the disposition or ability achieved by someone through the activity. The change of disposition is not obtained directly from a person's natural growth process. Likewise, according to [1] "The personalization of learning in schools opens up opportunities for the status of media education in general - given the positive correlation between giving greater decision-making powers to students and engagement levels. The challenge for schools in the future is to understand that the personalization of learning must be led by learners themselves and it is new media tools that give a perfect context for the ownership of subject matter and content, which makes for more effective learning ". So it can be understood that learning is an activity conducted by individuals that lead to changes in behavior in the form of knowledge (cognitive aspects), attitudes (affective aspects), skills (psychomotor aspects), the individual self thanks to the interaction between individuals with individuals or the environment. In learning is contained an activity done with all the senses to understand the meaning of relationships then apply the concepts generated to real situations. While mathematics is a complex, but very well-structured system that has many branches, at a low level of arithmetic and geometry. It is further expanded at a higher level and many new branches are added. Here are some mathematical definitions from various sources:

a. According to Ruseffendi (1991) cited by [5] mathematics is a symbolic language of deductive science that does not accept indictive proof, the science of order, and organized structure, ranging from undefined elements, to defined elements, to akorioma or postulate and finally to the proposition.

b. Meanwhile, according to Soedjadi (2000) cited by [5] essence of mathematics that has the object of abstract purpose, based on agreement, and a deductive mindset.

c. According to Johnson and Myklebust in [6] mathematics is a symbolic language whose practical function is to express quantitative and spatial relationships, while its theoretical function is to make it easier to think. So it can be taken that mathematics is a science that studies about the amounts that are known through the process of calculation and measurement, as well as about the organized structure.

The result of student's mathematics learning will surely be shown with achievement. According to [7] suggests "learning outcomes are the abilities that students have after receiving their learning experience". Meanwhile, according to Winkel in [8] suggests that the learning achievement is a proof of success that has been achieved by someone. Likewise with [9] "... the most effective pedagogies are those which involve 'weaving' between different activity types of knowledge processes". So the learning achievement is a realization of the potential skills or capacities a person possesses. Mastery of learning outcomes can be seen from the behavior, both behavior in the form of mastery of knowledge, thinking skills and motor skills. In school, the results of learning or achievement of this study can be seen from the mastery of students will the subjects that have been taken. The tools to measure learning achievement are called achievement test or achievement test compiled by teachers or lecturers who teach the relevant course [10]. In learning mathematics with achievement as a measure of success, of course, the learning model also influences it. Learning model is a pattern used as a guide in planning the learning in the classroom or tutorial. According to Arends in [3] learning model refers to the approach to be used, including learning objectives, stages in learning activities, learning environment and classroom management. In the Indonesian Language Dictionary by [11], conventional learning model means custom or traditional. Meanwhile, according to [12] "The method of lecturing is a traditional method because it has always been used as a tool of oral communication between teachers and students in educational interaction." According to Abdul Majid (2014: 151) conventional learning model is a way which is done in developing the learning process through narrative. Which has advantages and disadvantages:

a. The advantages of Conventional Learning Model

[13] states that, there are several advantages of the conventional learning model :

1. Does not require complicated preparation.

2. Can present a broad material.

3. Can provide the subjects that need to be highlighted.

4. Teachers can control the classroom situation.

5. Classroom organizations using conventional learning models can be simplified.

b. The weakness of Conventional Learning Model

[13] states that, there are some disadvantages of the conventional learning model :

1. Materials controlled by students are limited to what mastered by the teacher.

2. Conventional learning not accompanied by demonstrations can lead to verbalism.

3. Boring.

4. It is very difficult to know whether all students have understood what is explained or not.

Conventional learning is teacher-centered learning, in which the teacher delivers the oral learning, so sometimes there are some students who feel bored. To overcome the boredom of students who learn the effect of decreasing the spirit of learning mathematics, the understanding of the concept of algebraic operation of addition and reduction of integers tried to use miniature cars as an alternative to arouse students' mood in learning mathematics. Miniature cars are small car props used in helping the process of learning the concept of addition and reduction of integers. Miniature car is part of the learning media which is a tool that serves to explain some of the overall learning programs that are difficult to explain verbally [14].

Meanwhile, according to Gerlach and Ely in [14] suggests that the medium of learning has 3 characteristics which is an indication of why the media used and what can be done by the media that teachers may be less efficient to do. The characteristics are as follows:

\section{a. Fixative Features}

This feature describes the ability of the media to record, store, preserve, and reconstruct an event or object. 
b. Manipulative Characteristics

The transformation of an event, a time-consuming event can be presented to students within two or three minutes by shooting techniques. For example, how the process of larvae becomes a cocoon then becomes a butterfly can be accelerated by the photographic technique.

\begin{tabular}{|c|c|}
\hline Class & Students \\
\hline IV-A & 24 \\
\hline IV-B & 26 \\
\hline IV-C & 25 \\
\hline Total & 75 \\
\hline
\end{tabular}

c. Distributive Characteristics

Distributive features of the media allow an object or event to be transported through space, and simultaneously it is presented to a large number of students with similar relative experience stimuli about the event.

According to [15] "New technology is empowering children and offering new ways of sharing and interacting with their peers". Learning media can be interpreted as a type of learning tool component in the learning environment used as an intermediary to achieve goals between teachers to learners or vice versa. Similarly, from [16] also says "... that focuses on the media literature in the media and in the new media literature. schools has wide reaching extensions ... ". So a good math learning is that which involves intellectual and emotional students optimally. Students build their own concept of thought so that will facilitate his understanding of a material. One attempt to implement this is through the use of appropriate learning models for students. Learning method has a big enough influence in supporting the success of a learning process. The use of miniature cars in learning mathematics is expected to produce better learning achievement than using conventional learning methods that use the number line when explaining the concept of addition and reduction of integers. This can be described in the research chart as follows:

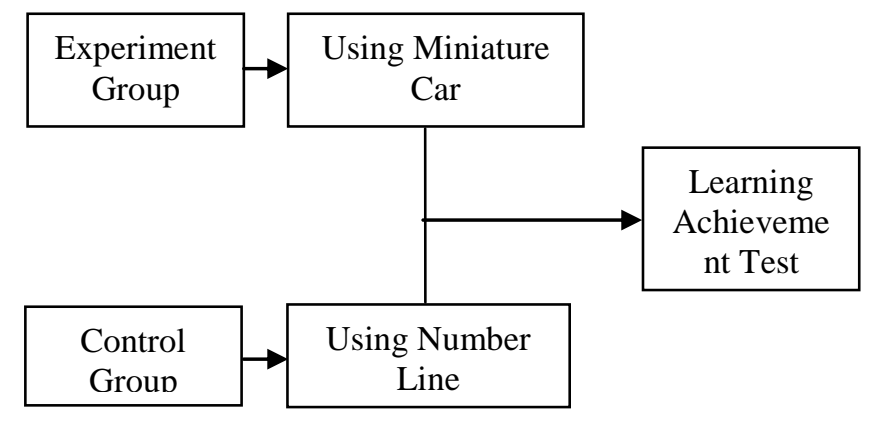

Figure 1. Flow of Research in fourth grade students of SDIT MTA Gemolong Sragen regency for academic year 2015/2016?".

\section{METHODS}

This research was conducted at SDIT MTA Gemolong, with address Kauman RT.08 RW.05, GemolongSubdistrict, Sragen Regency which was held in the even semester of academic year 2015/2016, starting in January 2016. The population of this research is 74 students of grade IV SDIT MTA GemolongSargen District for the academic year 2015/2016, with details of the class as follows:

Table 1. Research Population

The sampling technique used in this study was by cluster random sampling, by looking at the population as groups. In this case the class is seen as a unit of the group then each class is numbered to be randomized by lottery. The draw is held one stage with two rounds. The first class number that came out as the experiment group and the next outgoing class number were designated as the control group. Random sampling in the population is intended for each class in the population to be represented. From the results of random sampling, obtained class IV-A as experimental class and class IV-B as a control class. With many students of grade IV-A are 24 students and IV-B as many as 26 students.

The instrument used in this research is a written test in the form of multiple choice as much as 40 questions with four choices of answers. The test is material on the subjects of grade IV mathematics. According to [17], a test is said to be good as a measuring device must meet the following test requirements:

\section{Validity}

\section{Reliability}

For that to obtain accurate research data, firstly tested the test to determine the validity and reliability of the question.

\section{a. Test Validity}

After the test is held, the validity of each item can be known. In the product moment table, with $\mathrm{N}=25-1=24$ and a significant level of $5 \%$ can be obtained rtabel = 0.396 . The item is said to be valid if rhitung $>$ rtabel. And from 40 questions tested to 25 students from class IV C, obtained 33 valid questions and 7 others invalid. Seven invalid questions are number 2, 3, 5, 6, 7, 22, and 33 . Because invalid, the seven items are not used. In this research, the researcher took 30 questions that used to take the achievement data by not using item about the numbers 1,9 , and 15 because it is considered the rhitung value which is the lowest category of the valid question items.

\section{b. Test Reliability}

To calculate the reliability value of the question, each correct answer is given a value of one and every wrong answer given the value of 0 , while the formula used is the formula KR-20, Reliability calculation results using the formula KR-20 obtained value r11 $=0.921$ while 
rtabel $=0.396$. Because r11 $>$ rtabel then the problem goes on very reliable criteria.

In this study the tool used for data collection is a method of documentation in the form of value data Outer Anniversary Semester Odd grade IV SDIT MTA Gemolong and test methods in the form of multiple choice consisting of 40 items with four choices of answers.

In this study involves two variables, namely the independent variable use of miniature cars and the dependent variable of mathematics learning achievement. Data analysis technique used is statistical technique with analysis of variance (anava) two way. In addition to the two-way anava, used for the average equilibrium test of both classes, the Lilliefors test is used for the sample normality test, and Homogeneity Test.

\section{RESULTS AND DICUSSION}

\section{a. Pre-Requirement Test}

The data used for the prerequisite test is the data of the Ultimate Anniversary of Odd grade Semester SDIT MTA Gemolong of Sragen Regency for the academic year 2015/2016.

b. Initial Average Balance Test

The result of initial equilibrium test that has been done to both samples is zhitung $=1.488$ while from the table obtained z $(0,025 ; 50)=1,96$. Because zhitung $<\mathrm{z}(0,025$; $50)$ then Ho accepted. So it can be concluded that both groups come from a balanced population.

c. Normality test

From normality test done to class IV-A as experiment class and class IV-B as control class, obtained result $\operatorname{Lmax}=0,064$ and $\mathrm{L}(0,05 ; 50)=0,125$. This shows that Lmax $<$ Ltabel so it can be concluded that the sample of experimental class students and the control class comes from a normally distributed population.

\section{d. Homogeneity Test}

Homogeneity test conducted on both samples obtained result $\chi^{\wedge} 2$ count $=3,388$ while $\chi^{\wedge} 2$ table $=3,841$. Thus $\chi^{\wedge} 2$ count $<\chi^{\wedge} 2$ table. So it can be concluded that the initial capability data of both samples have homogeneous variance.

\section{Report After Treatment}

e. Normality test

The result of achievement normality test of all sample of experiment class and control class shows that Lmax = 0.086 with $\mathrm{L}(0,05 ; 50)=0,125$. So that $\operatorname{Lmax}<\mathrm{L}(0,05$; $50)$ is $0,086<0,125$, it shows that data of mathematics learning achievement of experiment class and control class come from normally distributed population.

\section{f. Homogeneity Test}

Calculation of homogeneity test of row 1 and row 2 of mathematics learning achievement data after subjects were given experimental treatment and control class obtained result $\chi^{\wedge} 2$ count $=0,561$ and $\chi^{\wedge} 2$ table $=$ 3,841. Thus $\chi^{\wedge} 2$ count $<\chi^{\wedge} 2$ table. Then it can be concluded that both samples have homogeneous variance.

\section{g. Hypothesis testing}

From the t test used to test the hypothesis obtained thitung $=2.4162$ while ttabel $=2.0106$. Then thitung >ttable so thitung $\in \mathrm{DK}$. His decision was Ho was rejected. Based on these calculations it can be concluded that "there are differences in mathematics learning achievement between students who were taught by using miniature cars with students taught by conventional methods in fourth grade students of SDIT MTA GemolongSragen regency for academic year 2015/2016".

\section{h. Discussion}

Based on the hypothesis test of student achievement mathematics data using $t$ test obtained tcount $=2.4162$ while ttabel $=2.0106$. Because thitunh $>$ ttabel is 2.4162> 2.0106 then $\mathrm{HO}$ is rejected. With the rejection of $\mathrm{HO}$ means "there is a difference in mathematics learning achievement between students who were taught by using miniature cars with students taught by conventional method in fourth grade students of SDIT MTA GemolongSragen regency for academic year 2015/2016". From these results, it can be concluded that the use of miniature cars contributes to better performance than the use of the number lines in conventional models. This is because this is because the use of miniature cars based on natural reasoning that has been accustomed to seen in everyday life so as to facilitate students to accept the explanation of the concept of addition and reduction of integers submitted by the teacher. The use of miniature cars in understanding the concept of addition and subtraction provides learning that is more meaningful and meaningful for students. Students are motivated to learn, improve their experience and learning knowledge, and can improve critical thinking, creative and high social taste so as to improve mathematics learning achievement.

\section{CONCLUSIONS}

Based on the study of theory and supported by the results of analysis and refers to the objectives of the problems that have been described in advance, it can be concluded that seen from the student achievement teaching use miniature car there is a positive influence in mastery of the concept of addition and reduction of integers fourth grade students SDIT MTA GemolongSragen Year Teaching $2015 / 2016$ compared with the use of line numbers on conventional learning, which has been shown hypothesized testing with $\mathrm{t}$ test obtained $\mathrm{t}$ count $=2.4162$ while ttabel $=$ 2.0106. So theoretically and practically the addition and subtraction operation of student understanding comprehension can be improved by using miniature cars that have been able to contribute to better performance differences. 


\section{ACKNOWLEDGEMENT}

The author would like to thank to the head of Veteran Bangun Nusantara University of Sukoharjo.

\section{REFERENCES}

[1] Cheung, C.K. Challenges and Opportunities for Media Education and Beyond. E-Learning and Digital Media Volume 7 Number 4 2010.

[2] Jenkins, H., Purushotma, R., Clinton, K., Weigel, M. \& Robison, A.J. Confronting the Challenges of Participatory Culture: media education for the 21st century. Chicago: Macarthur Foundation. 2006

[3] Suprijono, A. Cooperative Learning. Jakarta: BumiAksara. 2012

[4] Cloonan, A. Multimodality Pedagogies: a multiliteracies approach, International Journal of Learning, 15(9), 159-168. 2008

[5] Heruman. Model Pembelajaran Matematika. Bandung: RemajaRosdakarya.http://dx.doi.org/10.1177/1461444807076971 2007

[6] Abdurrahman. Pendidikan. Jakarta: PT AsliMahasatya . 2010/

[7] Sudjana, N. Penilaian Hasil Belajar. Bandung :RemajaRosdakarya. 2005.

[8] Hamdani.Strategi Belajar Mengajar. Bandung: BalaiPustaka. 2011.

[9] Cazden, C.B. Review of Ho WahKam\& Ruth Y.L. Wong (Eds) Language Policies and Language Education: the impact in East Asian countries in the next decade, 2nd edn (2004) and Ho WahKam\& Ruth Y.L. Wong (Eds) English Language Teaching in East Asia Today: changing policies and practices, 2nd edn (2004), Asia Pacific Journal of Education, 35(5), 784-788. 2006.

[10] Sukmadinata. Landasan Psikologi Proses Pendidikan. Bandung: PT RemajaRosdakarya. .2005.

[11] Poerwodarminta W.J.S.Kamus Besar Bahasa Indonesia, Jakarta: BalaiPustaka. .2007.

[12] Hamdayama. Model dan Metode Pembelajaran Kreatif dan Berkarakter. Bogor: Ghalia Indonesia. 2014.

[13] Majid, A. Pembelajaran Tematik Terpadu. Bandung: PT Remaja Rosdakarya. 2014.

[14] Musfiqon. Media dan Sumber Pembelajaran. Jakarta: Prestasi Pustakarya. 2012.

[15] Heim, J., Brandtzaeg, P.B., Hertzberg Kaare, B., Endestad, T. \&Torgersen, L. Children's Usage of Media Technologies and Psychosocial Factors, New Media and Society, 9, 425-454. 2007.

[16] Kellner, D. New Media and New Media Literacies: reconstructing education for the new millennium. in L. Lievrouw \& S. Livingstone (Eds) The Handbook of New Media. Los Angeles: Sage. 2002.

[17] Arikunto, Suharsimi. Dasar-Dasar Evaluasi Pendidikan. Jakarta: Bumi Aksara. 2008.

[18] Budi A, Januar. Belajar Pembelajaran. Universitas Veteran Bangun Nusantara Sukoharjo. 2012.

[19] Budiyono. Statistika Untuk Penelitian, Surakarta : UNS Press. 2009.

[20] Slametto. Belajar dan Faktor-faktor Yang Mempengaruhinya, Jakarta: RinekaCipta. 1998. 